Iraqi Journal of Veterinary Medicine Vol. 34, No. 1, 2010

\title{
Prenatal Study of Testes Growth and Histological Development \\ 2-Fetal Goat.
}

\author{
Amin,F.A.S.M. *
}

Coll. Vet. Med., Sulaimani University.
Alwan A.F. **

Coll. Vet. Med. Baghdad Uni.

\section{Accepted date 4/4/2010}

\section{Summary}

This study was conducted on 53 samples of female local Kurdi goats uterus contained one or two fetuses. These samples were collected from Sulaimani slaughter house, A total of 53genitlia were consisted of $36(67.92 \%)$ single and 17(32.08\%)twin fetuses, with a total of 70 fetus, of them 33(47.14\%) and 37(52. 86\%) were located in the right and left horns, respectively. The number of fetuses with macroscopically clear external sex organ was 55, the total number of male fetuses was 34(48.57\%) while the female was 21(30\%). The fetuses whose external organ could not be diagnosed were $15(21.42 \%)$. The weight of the fetal testes and the length of scrotum were increased steadily with an increasing in the fetal Crown Rump Length(CRL). When the CRL is $2.5-5 \mathrm{~cm}$ testes location is close to the kidney, while testes are located in the inguinal ring and/or scrotum at about $20-23$ and $28 \mathrm{~cm}$. Histological sections of testes showed the density of fibroblast layer and connective tissue capsules as well as the appearance of seminiferous tubles containing a few spermatogonia cells and small leydig cells at early stages of $\mathrm{CRL}=8 \mathrm{~cm}$. With an increasing in CRL, the seminiferous tubules filled with different types of spermatogonia cells, spermatocytes cells, increasing in number and size of sertoli and leydig cells. Different Types of spermatid were also present in sections of more than $20 \mathrm{~cm}$ CRL. The study indicated that the fetal testes secreted testosterone hormone which is essential for testes development and descending.

$$
\begin{aligned}
& \text { دراسة نمو والتظور النسيجي لخصى الاجنة } 2 \text { - اجنة المعز } \\
& \text { علي فاضل علوان } \\
& \text { فردون عبد الستار محمد امين } \\
& \text { كلية الطب البيطري - جامعة السليمانية كلية الطب البيطري/ جامعة بذاد } \\
& \text { الخلاصة }
\end{aligned}
$$

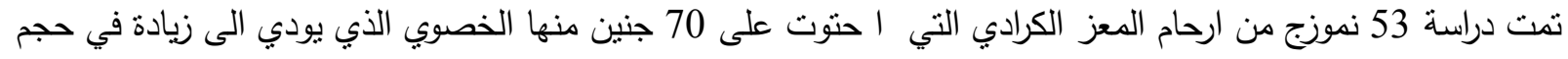

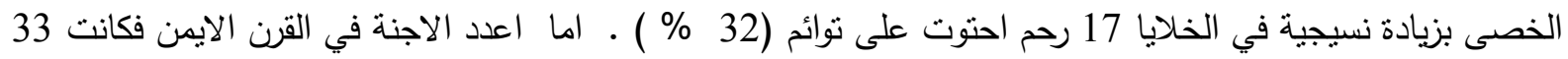

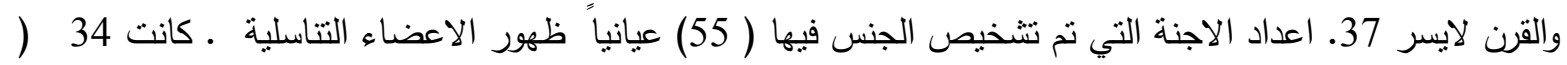

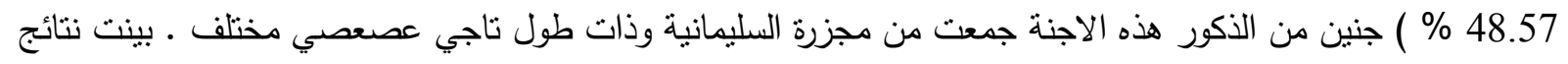

$$
\begin{aligned}
& \text { التجربة بان اوزان الاجنة والخصى واطوال كيس الصفن تزداد بزيادة طول التاجي العصعصي للجنين / سم ـ عندما يكون } \\
& \text { الطول } 2.5 \text { - } 5 \text { سم تكون الخصى ملاصقة للكلية , وجدت الاجنة بطول } 20 \text { - } 23 \text { سم , } 80 \text { - } 85 \text { يوم في الحلقة الاربية }
\end{aligned}
$$




\section{Iraqi Journal of Veterinary Medicine Vol. 34, No. 1, 2010}

$$
\begin{aligned}
& \text { وداخل كيس الصفن للجنة بطول } 28 \text { سم , } 100 \text { يوم ـ الدراسة النسيجية للخصى الاجنة بينت بان الخصى عندما يكون طول } \\
& \text { التاجي العصعصي } 8 \text { سم تقريباً تحوي على نبيبات منوية فيها بعض الخلايا الجرثومية وخلايا ليدك خارج النبيب ـ بزيادة طول } \\
& \text { التاجي العصعصي تحصل الزيادة في انواع الخلايا الجرثومية داخل النبيب وخلايا سيرتولي , وتزداد اعداد و احجام خلايا } \\
& \text { ليدك ـ ظهور طلايع النطف عند طول } 24 \text { سم بعمر } 80 \text { - } 85 \text { يوم تقريباً .ؤقد أستتتج من هذه الدراسة بان خصى الاجنة لها } \\
& \text { القابلية على افراز هرمون الثحمون الجرثومية والجسمية المختلفة في خصى الاجنة وظهور طلائع النطف في التلث الاخير } \\
& \text { من عمر الجنين • ويساعد هرمون الثحمون الخصوي في نزول الخصى الى كيس الصفن }
\end{aligned}
$$

\section{INTRODUCTION}

In the adult male of many mammalian species, libido and testicular function, which are thought to be mediated through alterations in gonadotrophin secretion from the pituitary gland. The development and function of the testes in sheep fetuses are known to be critically depends on circulating fetal gonadotrophin concentration (1). It is clear that the testis is capable of prouducing various androgen in sheep fetus (2.). The weight of fetal goat testes is increased about 8 times between days 60-80 of gestation period ,during this time sertoli cells, leydig cells, and spermatogonia appear in histological picture, therefore, the weight was increased 4 times between days 100-140 of gestation (3).Amann (4)reported that the weight of testis is related to the nutritional levels but not to the age. The faster growth stage is between 70-100 days of postnatal life. Monet-Kuntz, et.al.(5) reported after birth the seminferious are small, inactive and closed, after 95 days of age they grow and develope .

There was no data available considering the size, location, of fetal testes as well as the histological study of the development of the fetal testes in goats, The present study is designed to investigate the histological development of fetal testes., to determine its location, size, and migration of fetal testes goats throughout intra uterine life .

\section{Materials and Methods}

Fifty three (53) local Kuridi goats(6) genitalia samples contains one or two foetuses were collected from slaughter house in Sulaimani Governorate. Immediately after evasceration, the genitalia were separately placed in plastic bags and transported to the laboratory of Veterinary Teaching Hospital at the College of Veterinary Medicine Sulaimani Uni.. The genitalia containing foetuses were freed carefully from extraneous tissues. The weight and location of the foetus were recorded. The foetuses CRL was measured using calibre virner (Guogence Battery SR441.55V) and the age of the foetuses in days was calculated, according to Noakes.( 7),

Foetal sex was determined by visual examination when the foetal external genitalia in the male or the female appeared macroscopically clearly. The abdominal cavity was opened to determine 1-foetal sex ,in foetuses which their sex could not determined externally. 2- to estimated the location of the foetal testes and the testes descending from the kidney.

The weight of the foetuses and both testes were weighted using (Sensitive electric balance (PR5003comparatorMettlerToledo).

Histological Techniques: According to the studies of Luna(8). The blocks were cut by rotary microtome (Mod.1130/Biocut) into sections (5-6 microine) and stainedwith hematoxylin and eosin.

The SAS(9) program was used for statistical analysis . Least significant difference (LSD)was used to compare the significant differences between the means. 
Iraqi Journal of Veterinary Medicine Vol. 34, No. 1, 2010

\section{RESULTS}

A total of 53 of genitalia were collected, of them 36(67.92) contain single and $17(32.08 \%)$ contain twin fetuses. The total number of fetuses $70(47.14 \%)$ of them 33 in the right horn. The total number of male fetuses with different ages was 34(48.57\%), while the fetuses whose external sex organ could not be diagnosed was 15(21.42\%).(table1).

Table 1: The Relation of Caprine fetuses with fetal weight (gm), fetal sex and fetal location in various fetal CRL in single and twin pregnant fetuses. (Mean \pm S.E.)

\begin{tabular}{|c|c|c|c|c|c|c|c|}
\hline $\begin{array}{c}\text { Fetal } \\
\text { No. }\end{array}$ & $\begin{array}{l}\text { CRL } \\
(\mathrm{cm})\end{array}$ & $\begin{array}{l}\text { Age } \\
\text { (days) }\end{array}$ & $\begin{array}{c}\text { Fetal } \\
\text { Weight(gm) }\end{array}$ & Male & Female & $\begin{array}{l}\text { Right } \\
\text { Horn }\end{array}$ & $\begin{array}{l}\text { Left } \\
\text { Horn }\end{array}$ \\
\hline $\begin{array}{c}\mathrm{No}=15 \\
\text { Single=7 } \\
\text { Twin=4 }\end{array}$ & $\begin{array}{l}1-2 \\
(1.8)\end{array}$ & $\begin{array}{r}42-44 \\
(43.68) \\
\end{array}$ & $\begin{array}{c}G \\
8.315 \pm 0.323\end{array}$ & & - & 5 & 10 \\
\hline $\begin{array}{c}\mathrm{No}=15 \\
\text { Single=7 } \\
\text { Twin=4 }\end{array}$ & $\begin{array}{l}2.5-5 \\
(3.25)\end{array}$ & 46.9 & $\begin{array}{c}\mathrm{G} \\
13.825 \pm 0.097\end{array}$ & 9 & 6 & 7 & 8 \\
\hline $\begin{array}{c}\mathrm{No}=8 \\
\text { Single=2 } \\
\text { Twin=3 }\end{array}$ & $\begin{array}{l}7-10 \\
(8.2)\end{array}$ & 57.6 & $\begin{array}{c}\mathrm{F} \\
27.375 \pm 0.508\end{array}$ & 5 & 3 & 4 & 4 \\
\hline $\begin{array}{c}\mathrm{No}=10 \\
\text { Single=4 } \\
\text { Twin=3 }\end{array}$ & $\begin{array}{l}11-14 \\
(12.7)\end{array}$ & $\begin{array}{l}63-68 \\
(66.3)\end{array}$ & $\begin{array}{c}E \\
87 \pm 0.394\end{array}$ & 9 & 1 & 4 & 6 \\
\hline $\begin{array}{c}\mathrm{No}=8 \\
\text { Single }=8\end{array}$ & $\begin{array}{c}15-18 \\
(16.32)\end{array}$ & $\begin{array}{c}71-78 \\
(74.15)\end{array}$ & $\begin{array}{c}\mathrm{D} \\
187.143 \pm 0.516\end{array}$ & 3 & 5 & 7 & 1 \\
\hline $\begin{array}{c}\mathrm{No}=8 \\
\text { Single }=2 \\
\text { Twin=3 }\end{array}$ & $\begin{array}{c}20-23 \\
(21)\end{array}$ & $\begin{array}{c}81-88 \\
(83.63)\end{array}$ & $\begin{array}{c}\mathrm{C} \\
375 \pm 1.29\end{array}$ & 6 & 2 & 4 & 4 \\
\hline $\begin{array}{c}\mathrm{No}=4 \\
\text { Single }=4\end{array}$ & $\begin{array}{c}28-30 \\
(29.75)\end{array}$ & $\begin{array}{l}98-103 \\
(101.3)\end{array}$ & $\begin{array}{c}\mathrm{B} \\
1140 \pm 3.946\end{array}$ & 2 & 2 & 1 & 3 \\
\hline $\begin{array}{c}\mathrm{No}=2 \\
\text { Single }=2\end{array}$ & 37 & 118 & $\begin{array}{c}\mathrm{A} \\
2195 \pm 0.288\end{array}$ & - & 2 & 2 & \\
\hline LSD & & & 38.479 & & & & \\
\hline
\end{tabular}




\section{Iraqi Journal of Veterinary Medicine Vol. 34, No. 1, 2010}

Table 2 shows the developmental stages of male fetuses, the table shows that the weights of testes and the length of fetal scrotum were steadily increased from $3.25 \mathrm{~cm}$ CRL to $29.75 \mathrm{~cm}$ CRL, it also shows the descending of fetal testes in different CRL; when the CRL is $3.25 \mathrm{~cm}(46.8$ day), the location of the testes is close to the kidney, $12.7 \mathrm{~cm} \mathrm{CRL}(66.6$ day), the location of the testes is $0.9 \mathrm{~cm}$ way from the kidney with clear penis, fetal length $21 \mathrm{~cm}$ CRL ( 84 day), the testes are located in the inguinal ring and/or scrotum.

Table 2: The Development of the Goats Fetal Male Genitalia (M+ S.E.).

\begin{tabular}{|c|c|c|c|c|}
\hline $\begin{array}{c}\text { Fetal } \\
\text { No. }\end{array}$ & $\begin{array}{c}\text { CRL } \\
(\mathrm{cm})\end{array}$ & $\begin{array}{c}\text { Testes weight } \\
(\mathrm{gm})\end{array}$ & $\begin{array}{c}\text { Scrotum length } \\
(\mathrm{cm})\end{array}$ & Testes location \\
\hline 9 & $\begin{array}{c}2.5-5 \\
(3.25)\end{array}$ & $\begin{array}{c}0.013 \\
\pm \\
0.019\end{array}$ & 0.20 & Close to kidney \\
\hline 5 & $\begin{array}{c}7-10 \\
(8.2)\end{array}$ & $\begin{array}{c}0.014 \\
\pm \\
0.012\end{array}$ & 0.35 & Close to kidney \\
\hline 9 & $\begin{array}{c}11-14 \\
(12.7)\end{array}$ & $\begin{array}{c}0.054 \\
\pm\end{array}$ & 0.75 & $\begin{array}{c}0.9 \mathrm{~cm} \text { away } \\
\text { from kidney } \\
\text { with clear penis }\end{array}$ \\
\hline 3 & $\begin{array}{c}0.013 \\
(15-18\end{array}$ & $\begin{array}{c}0.084 \\
\pm\end{array}$ & 1.7 & $\begin{array}{c}1.2 \text { cm away fro } \\
\text { kidney }\end{array}$ \\
\hline 6 & $\begin{array}{c}5.060 \\
(21)\end{array}$ & $\begin{array}{c} \pm .52 \\
\pm\end{array}$ & 2.1 & $\begin{array}{c}\text { Scrotum }+ \\
\text { inguinal ring }\end{array}$ \\
\hline 4 & $28-30$ & 0.050 & & \\
& $(29.75)$ & $\begin{array}{c} \pm \\
0.150\end{array}$ & 2.62 & scrotum \\
\hline
\end{tabular}

The histological development goat fetal testes were followed up from early crown rump length $=8 \mathrm{~cm}$ CRL, the sections showed that the development of fetal testes which showed few seminiferous tubules containing few spermatogonium cells adjacent to the basement membrane of the seminiferous tubules immature sertoli cells and leydig cells (Fig.1). The seminiferous tubules appeared embedded in loose connective tissues and stroma which also contained vessels, and leydig cells. When goat fetal $\mathrm{CRL}=12 \mathrm{~cm}$ (Fig2), the sections show an outer thin layer of fibrous capsule, tunica albuginea, surrounded the testis(Fig2). Tunica albuginea divided the interior of the testis into the lobuli testis. Histological section, showed the density of fibroblast layer and connective tissue capsules, they are usually concentrated on the posterior aspect of the testis adjacent to the epididymis. The testis also showed convoluted seminiferous tubules with spermatogonia cells . Sections fetal $\mathrm{CRL}=20.3 \mathrm{~cm}$, appeared with seminiferous tubules filled with different types of the spermatogonia and spermatocytes cells, with an increase in the number of sertoli cells. Leydig cells, and metamorphosis spermatid inside tubules. The tubules are covered externally by fibrous tissues and fibroblast cells, (figure3). . Fig4 show the seminiferous tubules lined with complex germinal epithelium, the epithelium rests upon a thin basal lamina and is covered externally by fibroblast and cells with the characteristics of smooth muscle cells (myoid cells)., The presence of crowded leydig cells between tubules can be observed in fetal CRL=28 


\section{Iraqi Journal of Veterinary Medicine Vol. 34, No. 1, 2010}

and $30 \mathrm{~cm}$ the sections are showing also, different types of spermatid metamorphosis developed in seminiferous tubules, leydig cells between seminiferous tubules (Figures5 and6).

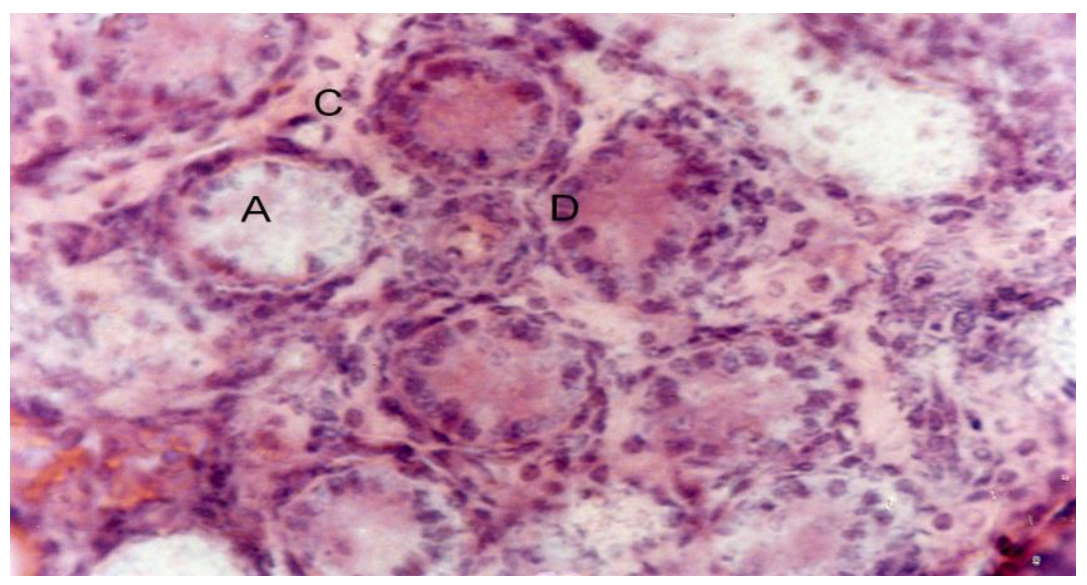

Fig.(1). Fetal Goat Tests CRL= $8 \mathrm{~cm} . H$. and E. X $40 \mathrm{~A}=$ Seminiferous tubules. $\mathrm{C}=$ Leydig cells.

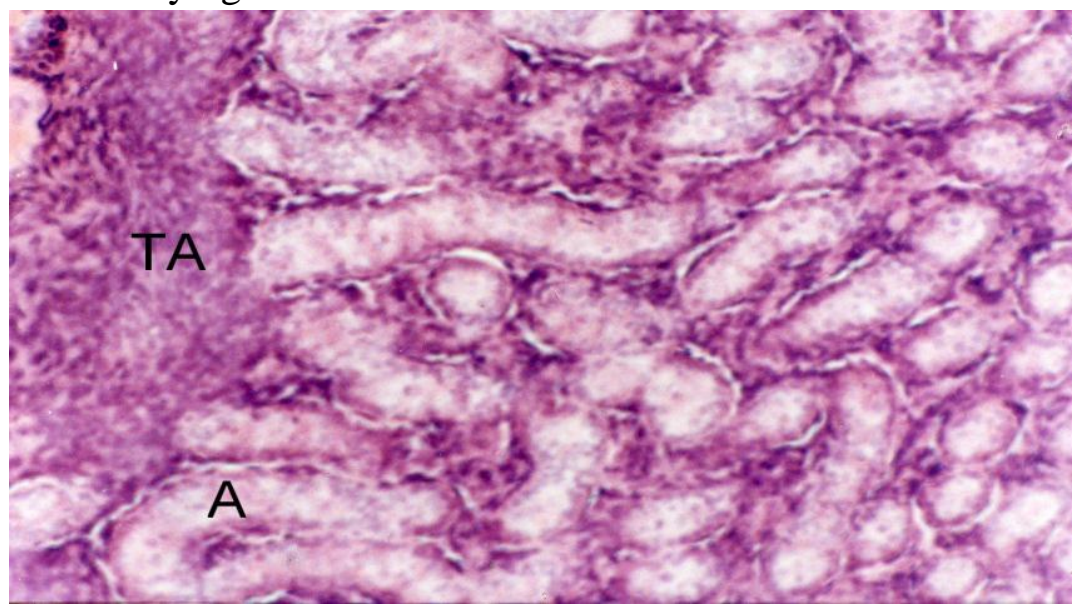

Fig. (2). Fetal Goat Tests CRL=12 cm H. and E. X40. $A=$ Seminiferous convoluted tubules. $\mathrm{T} A=$ Tunica albuginea . 
Iraqi Journal of Veterinary Medicine Vol. 34, No. 1, 2010

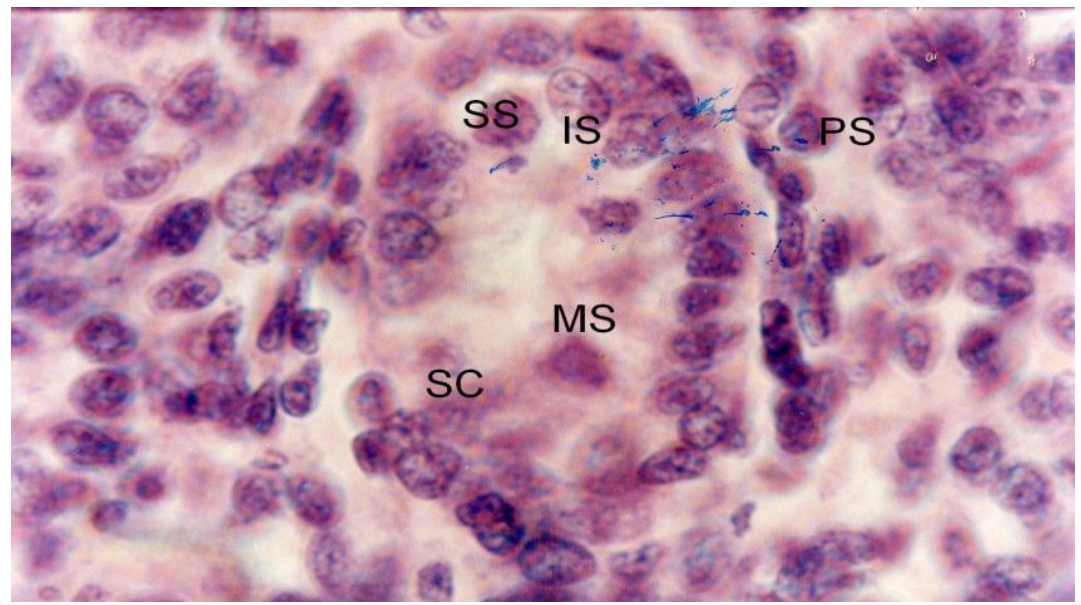

Fig. (3). Fetal Goat Testes. CRL $=20.3 \mathrm{~cm}$.H.and E. X100. Sertoli Cells. $\quad$ SS $=$ Spermatocyte Secondary Spermatocyte .IS=Intermediate Spermatogonium Spermatid .

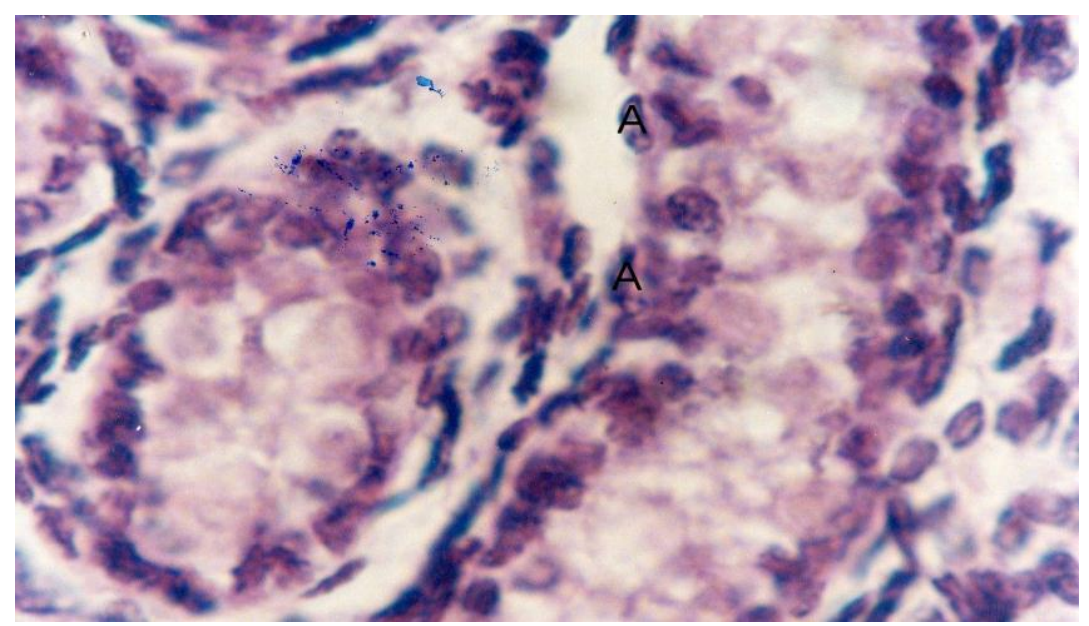

Fig.(4). Fetal goat Testes CRL $=24$. H and E. X 100.

$\mathrm{A}=$ Seminiferous tubules showed the basement members with myoid cells.

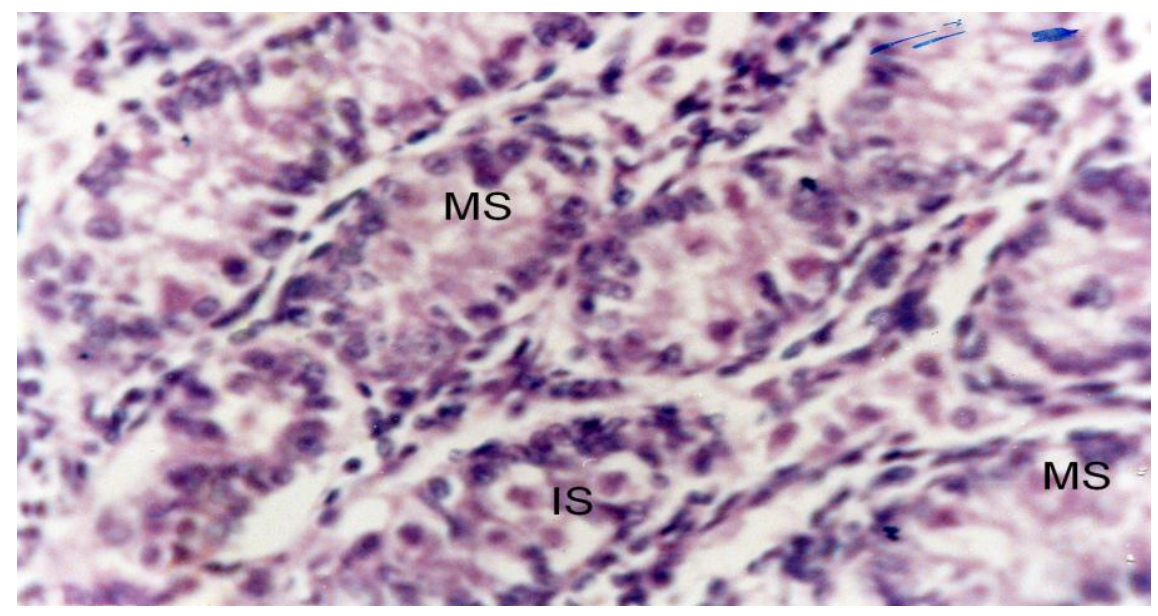


Iraqi Journal of Veterinary Medicine Vol. 34, No. 1, 2010

Fig.(5). Fetal Goat Testes CRL=28 cm. H and E. X 40

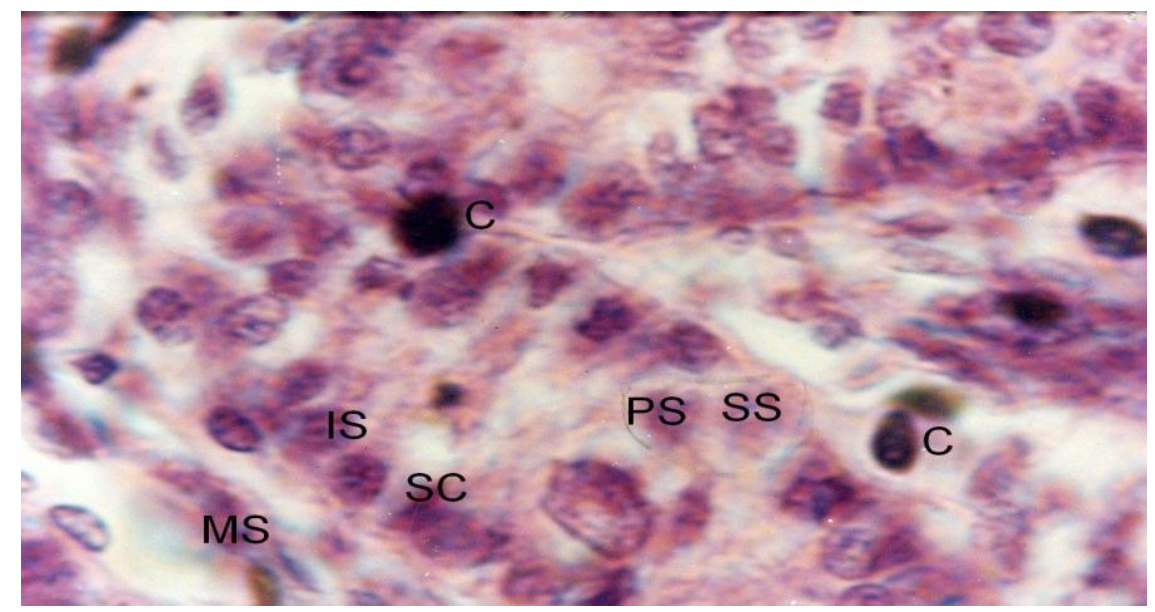

Fig. ( 6 ). Fetal Goat Testes CRL $=30 \mathrm{~cm} \mathrm{H.} \mathrm{and} \mathrm{E.} \mathrm{X100.} \quad$ C= Laydig Cell. IS= Intermediate Spermatogonium PS = Primary Spermatocyte SS = Secondary Spermatocyte $\quad \mathrm{SC}=$ Sertoli Cell $\quad$ MS = Metamorphosis Spermatide

\section{DISCUSSION}

Fetal testis weight, migration and histological development of different germinal cells in the seminiferous tubules and interstitial cells were followed. There is a few scattered reports about the histology of the fetal goats testes. The results demonstrate that the weight of fetal testes and the length of fetal scrotum increased with the advancing of age of the fetus (increasing CRL). Table 1 were similar to those observed by other ( 3 and 10). The appearance of the testes in the inguinal ring and or scrotum in male fetuses (table 2). These observations are similar to those of reported by others(11 and12).

Spermatogonium cells and a few leydig cells present in seminiferous tubules when the fetal $\mathrm{CRL}=8 \mathrm{~cm}$ in goats (Fig. 1) The germinal different cells increased in number and size with an increasing of the testes weight as well as the presence of leydig cells at early stages of fetal development .It was indicated that the testes could produce testosterone which is important for the regulation of the descending of the testes and growth development. This result agreed with that observed by( 2 and 13), who reported that fetal sheep testis is capable of producing androgen. Monet-Kuntz, et.al.,(5) reported after birth the seminferious are small, inactive and closed, after 95 days of age they grow and develope .

Histological section describes the presence of large leydig cells in the shape (Fig3.). At the same time the presence of different types of spermatogonium and spermatocytes cells with few metamorphosis spermatid .The faster growth stage is between 70-100 days of postnatal life (5). Figure (5 and 6)., show increases in the numbers and development stages of different types of 


\section{Iraqi Journal of Veterinary Medicine Vol. 34, No. 1, 2010}

metamorphosis spermatid in seminiferous tubules, when the testes are in the scrotum region, no mature spermatid appear in the section. This indicates that the formation of the spermatid could be after birth in seminiferouse sections or in epididymis. Hochereau-de Revierse(3).reported the presence of sertoli cells, leydig cells and spermatogonia appear in histological picture in fetal goat testis around 100-140 days of gestation.Ibrahem (14)reported no sperm could be seen before 6-8 weeks after birth in seminiferouse sections or in epididymis. Nathanielsz (15) recorded that the first appearance of spermatozoa in testes at about 34 days after birth in sheep Ibrahem (14) described in 16 weeks old kids sperms are appear in semen fluid .The histological picture, the wall testicular capsule development appear complete in late gestation when the inner of most of the layers of tunica vasculosa appear with tunica albugina and seminiferous tubules. The same pictue reported by (16).in adult buck .

\section{References}

1.Brooks AN Mc Neilly AS and Thomas GB(1995). Role of GnRH in the ontogeny and regulation of the fetal hypothalamo-pituitary-gonadal axis in sheep. J Reprod Fertil. Supple. 49:163-175.

2.Attal J.(1969). Levels of testosterone androstenedione, estrone and estradiol 17 bata in the testis of fetal sheep . Endocrinology . 280-289

3.Hochereau de Reviers MTM and Sock M. (1997).The Male ReproductionBiology.In; Prolific Ovine Breed. $2^{\text {nd }}$ International Workshop IM Bodin Land Moneir L Paris France.pp. 40-43

4.Amman RP (1989). Reproductive capacity of dairy bulls spermatogenesis and testes germ cells degeneration. Am.J.Anat.110:69-78.

5.Monet-Kuntz C Hochereau de Reviers MT and Terqui M.(1984). Variation in testicular androgen receptors and histology of the lamb testis from birth to puberty. $\mathrm{J}$ Reprod Fertil.70:203-210.

6.Gall C. (1996).Goat breeds of the Word. Bohler Verlag, Wurzburg, Germany. 96.Pp.79. Noaks De Parkinson TT England JCW and Arthur GH .(2002). In: Veterinary Reproduction Obstetrics. $8^{\text {th }}$ Ed Elsevier Sci Ltd.Pp. 399-409.

8.Luna LG.(1968). Manual of Histological Staining Methods of the Armed Forces Institute of Patholoy. $3^{\text {rd }}$ editition McGrow-HillBook Com. New York. 9.

9.SAS. sas/Stat (2007).users guide for personal computers SAS Institute Inc Cary NC. USA.

10. Kadu MS and Kaikini AS (1987). Prenatal development of caprin foettus. Indian J Anim .Sci. 579 : 962-969.

11.Bearden HJ Fuqay JW and Willard ST.(2004). In: Applied Animal Reproduction. $6^{\text {th }}$ edit,Pearson education, Inc. USA.

12. Chenoweth PJ and Kastlic JB. (2007).Clinical reproductive physiology and endocrinology of bulls. In: Current Therapy in Large Animal Theriogenology. RS Youngquist and WR 


\section{Iraqi Journal of Veterinary Medicine Vol. 34, No. 1, 2010}

Threlfall $2^{\text {nd }}$ edit. Sunders, an imprint of Elsevier Inc. USA. 221-228.

13.Mongkonpunya K Lin XC Noden PA Oxender WD and Hafs HD (1975).Androgen in the Bovine Fetus and Dam. Pro.Soc Exp Biol Med.148 : 389 -394.

14.Ibrahim NS.(2006). Effect of Haemi-castration and GnRH treatment of Young Buck on pubertal and the Levels of ICSH and Testosterone hormones. PhD These Depart. Surg Obest Vet Med Collg Baghdad Uni. PP:79-82.

15.Nathanielzs PW. (1976).In;- Fetal Endocrinology .In: An Experimental Approch.. Vol1.North Holland. Pub. Comp. New York Oxford. pp.31-35.

16.Hasan YD.(2008). The sequence events of spermatogenesis and spermiogensis in adult (Indogenous ) goat. MSc Thesis Anatomy and Histology Department College of Veterinary Medicine Baghdad University. 